\title{
CYTOCHEMICAL LOCALIZATION OF ADENYL CYCLASE IN THE RAT UTERUS
}

\author{
N. SANANES AND A. PSYGHOYOS \\ Laboratoire de Physiologie de la Reproduction, C.N.R.S. Equipe de Recherche 122, \\ Hôpital de Bicêtre, 94270 Kremlin-Bicêtre, France
}

(Received 8th October 1973)

\begin{abstract}
Summary. The cellular localization of uterine adenyl cyclase in rats was demonstrated at the ultrastructural level by a cytochemical technique. Following ovariectomy, oestradiol was shown to induce a high level of adenyl cyclase activity on the apical plasma membrane of the luminal epithelial cells. This oestradiol effect was strongly reduced by pretreatment with progesterone.
\end{abstract}

Ovum implantation in the rat depends on a sequential interplay between progesterone and oestradiol (review by Psychoyos, 1973). The mechanisms by which these ovarian hormones exert their effects on the uterus are not clearly understood. Due to the cellular heterogeneity of the uterus, continued progress in this field will be dependent in part on the application of appropriate cytochemical techniques. Cyclic adenosine $3^{\prime}: 5^{\prime}$-monophosphate (cAMP) is known to mediate numerous specific hormonal effects (Robinson, Butcher \& Sutherland, 1971) and an oestrogen-dependent elevation of cAMP has been biochemically assayed in uterine extracts (Szego \& Davis, 1967; Rosenfeld \& O'Malley, 1970). Formation of this cyclic nucleotide results from the action of adenyl cyclase on ATP, according to the reaction:

$$
\text { ATP } \stackrel{\text { adenyl cyclase }}{\longrightarrow} \text { cAMP + pyrophosphate }
$$

The purpose of the present investigation was to identify which uterine cells respond to oestradiol by an increase in adenyl cyclase activity and to study the effects of sequential progesterone-oestradiol treatments on the cellular localization of the enzymatic activity. The cytochemical technique used for the detection of adenyl cyclase was one employed by Reik, Petzold, Higgins, Greengard \& Barrnett (1970) for the demonstration of this enzyme in liver. The procedure involves the precipitation by lead ions of pyrophosphate liberated from ATP by adenyl cyclase. Lead pyrophosphate precipitates are observed at the ultrastructural level as electron-dense aggregates located at, or in close proximity to, the site of enzyme activity.

Adult female Wistar Rats were ovariectomized on the day after oestrus, designated as Day 0. The animals were allocated to five groups and were killed by decapitation on Day 9 . The rats in Group 1 received a single dose of $0.1 \mu \mathrm{g}$ oestradiol-17 $30 \mathrm{~min}$ before autopsy. Those in Group 2 received $5 \mathrm{mg}$ progesterone $1 \frac{1}{2} \mathrm{hr}$ before autopsy. The rats in Group 3 received $5 \mathrm{mg}$ progester- 
one on Days 7, 8 and 9 and were killed $1 \frac{1}{2} \mathrm{hr}$ after the last injection. The rats in Group 4 were treated as in Group 3, but received in addition $0 \cdot 1 \mu \mathrm{g}$ oestradiol-17 330 min before autopsy. Group-5 animals served as controls and received the injection vehicles: either $0.25 \mathrm{ml}$ of $1 \%$ ethanol in $0.9 \% \mathrm{NaCl}$ solution, injected intraperitoneally as in the case of oestradiol treatment, or $0.25 \mathrm{ml}$ sesame oil, administered subcutaneously as in the case of progesterone treatment. Immediately after decapitation, uteri were trimmed of adipose tissue and placed in cold $1.0 \%$ glutaraldehyde in a $0.05 \mathrm{M}$-cacodylatenitrate buffer, $\mathrm{pH} 7 \cdot 4$, containing $4.5 \%$ dextrose. The uterine horns were fixed for $30 \mathrm{~min}$ at room temperature during which they were cut into slices about $2 \mathrm{~mm}$ in thickness. The tissue slices were washed in $0.05 \mathrm{M}$-cacodylate-nitratedextrose buffer and stored overnight at $4^{\circ} \mathrm{C}$. Each slice was then cut into four blocks and incubated for $30 \mathrm{~min}$ at $30^{\circ} \mathrm{C}$ in $1 \mathrm{ml}$ of a medium of the following composition: 80 mm-tris-maleate buffer, $\mathrm{pH} \mathrm{7.4,8.0 \%} \mathrm{dextrose,} 20 \mathrm{~mm}$ -

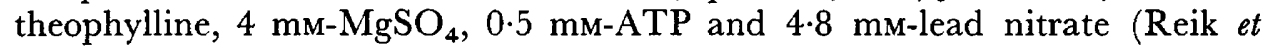
al., 1970). The blocks were then rapidly rinsed in ice-cold tris-maleatedextrose buffer and post-fixed for $45 \mathrm{~min}$ in $1.0 \%$ osmium tetroxide in 0.05 M-veronal-acetate buffer, $\mathrm{pH} 7 \cdot 4$, containing $7.5 \%$ sucrose, after which the specimens were dehydrated in a graded ethanol series and embedded in Epon 812. Ultrathin sections were cut on an LKB ultramicrotome, stained with uranyl acetate and lead citrate and examined with a Siemens Elmiscop 101.

Under all hormonal conditions studied, including the ovariectomized controls, a baseline level of adenyl cyclase activity was detected in association with the endothelial cells of the endometrial capillaries. Enzyme activity was distributed over the surface of these cells, and was also found in pinocytotic vesicles (Pl. 1, Fig. 3), whereas the hormonally dependent adenyl cyclase activity was exclusively localized at the apical plasma membrane of luminal epithelial cells. Under the hormonal conditions of this study, adenyl cyclase activity was never seen in association with either the lateral or basal surfaces of the epithelial cells.

When oestradiol was injected alone (Group 1), a continuous coat of leadphosphate precipitate was deposited over the entire surface of the apical plasma membranes of the luminal epithelium (Pl. 1, Fig. 2). With a single dose of progesterone (Group 2), the epithelial surfaces were always free of reaction product (PI. 2, Fig. 4), as in the case of the ovariectomized controls (Group 5) (Pl. 1, Fig. 1). By contrast, repeated injections of progesterone (Group 3) resulted in low levels of demonstrable enzymatic activity which was restricted

\section{EXPLANATION OF PLATE 1}

Fig. 1. Smooth apical surfaces of uterine epithelium (Ep) in an ovariectomized control rat showing absence of lead-phosphate precipitates. $\mathrm{mV}=$ microvilli. $\times 40,000$.

Fig. 2. Uterine luminal epithelium of an ovariectomized rat treated with $0 \cdot 1 \mu \mathrm{g}$ oestradiol 30 min before autopsy. Uniform intense adenyl cyclase activity is visible along the entire apical surface of each epithelial cell, including the numerous large microvilli. $x$ 40,000 .

FIG. 3. An endometrial capillary of an ovariectomized control rat showing abundant deposits of lead phosphate along the plasma membranes of the uterine endothelial cells (End). These deposits clearly delineate pinocytotic vesicles (arrows) and accumulate as masses within the capillary lumen (CL). $\times 24,000$. 

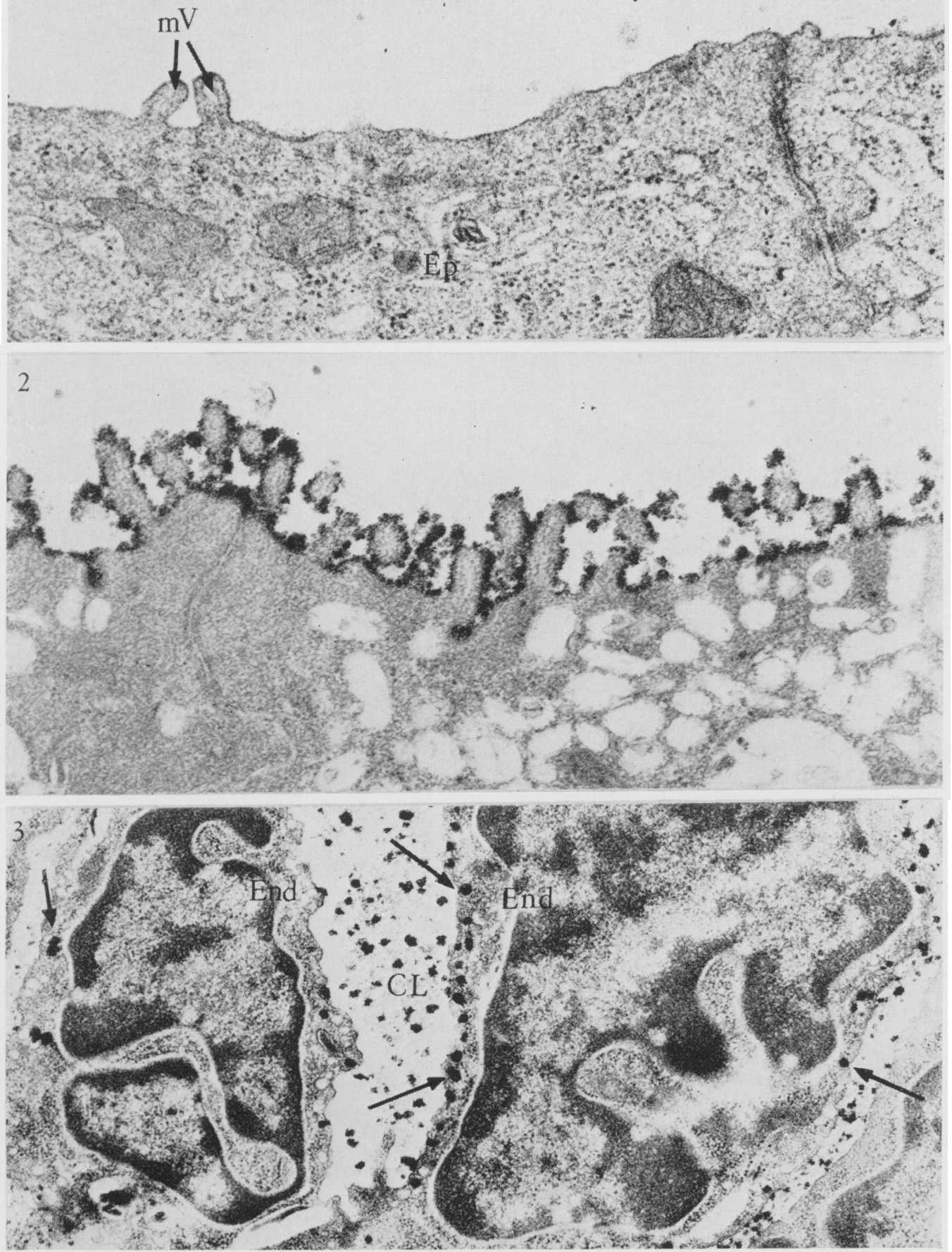


\section{PLA'lE 2}

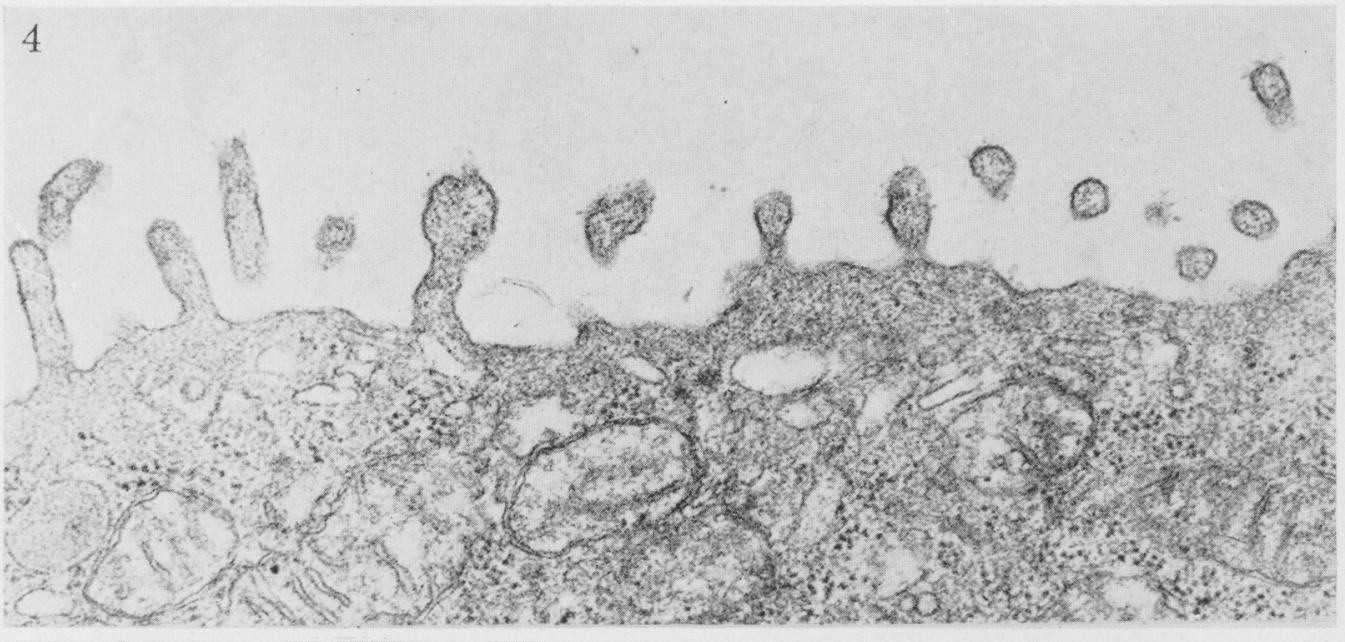

\section{5}
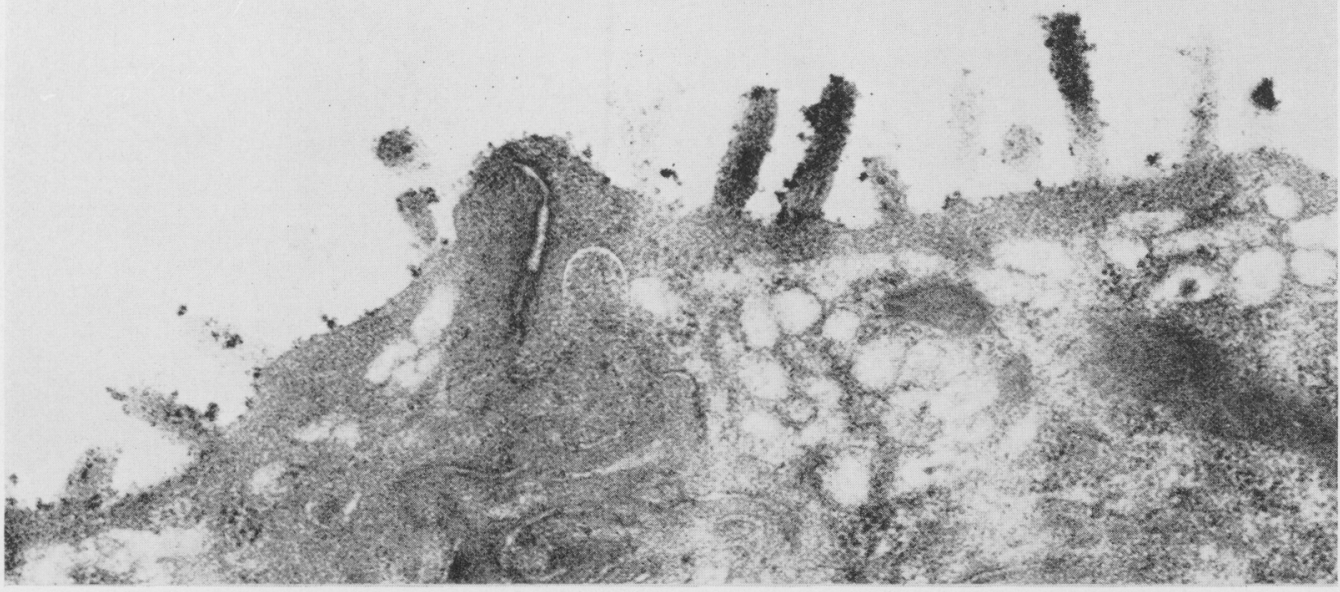

6

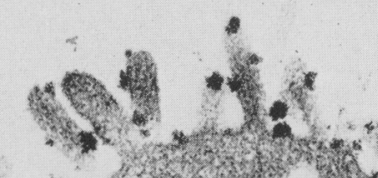

4.

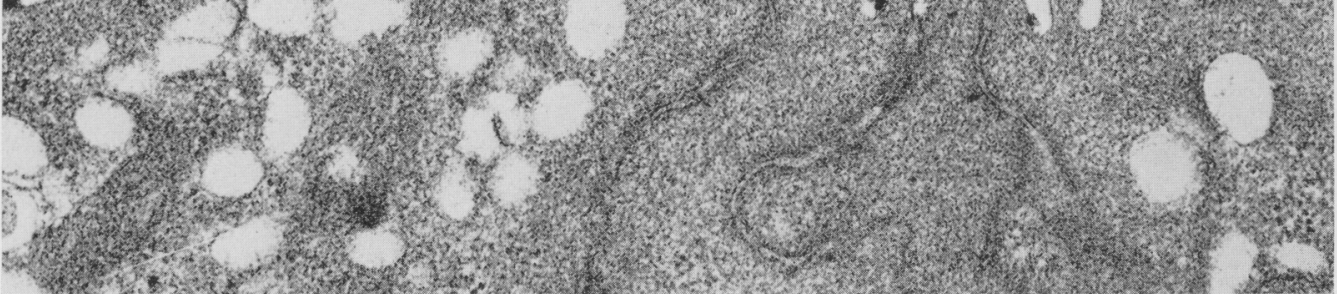


to the apical microvilli of occasional epithelial cells (Pl. 2, Fig. 5). The same sequence of progesterone administration followed by oestradiol (Group 4) gave a consistent reaction product at the apical surface of all epithelial cells (Pl. 2, Fig. 6). Enzymatic activity, however, was quantitatively reduced compared to that seen after the administration of oestradiol without prior progesterone treatment (Pl. 1, Fig. 1).

Biochemical assays have demonstrated that the uterine cAMP concentration, which shows a baseline level in ovariectomized rats (Szego \& Davis, 1967; Rosenfeld \& O'Malley, 1970), doubles in value after the administration of oestrogen (Szego \& Davis, 1967). Correspondingly, our observations indicate that the base-line production of the cyclic nucleotide can be assigned to the intrinsic adenyl cyclase activity of the endothelial cells lining the vasculature of the endometrium. The rapid uterine cAMP elevation elicited by oestradiol can definitely be assigned to the activity of the adenyl cyclase located at the apex of the luminal epithelial cells.

Our findings show that prior exposure of uterus to the action of progesterone for a 72-hr period almost entirely prevents the stimulatory effect of oestradiol on the epithelial adenyl cyclase activity. This antagonism parallels the inhibitory action of progesterone on the oestradiol-binding and oestradiol-induced uridine uptake by the epithelial cells (Tachi, Tachi \& Lindner, 1972). It is interesting to note that, whereas this uridine uptake is redirected from the epithelium to the sub-epithelial stroma cells (Tachi et al., 1972), the distribution pattern of the adenyl cyclase activity between the uterine cellular components is unaffected by pre-administration of progesterone.

This research was supported by Grants from the Ford Foundation and the Population Council.

\section{REFERENGES}

Psychoyos, A. (1973) Hormonal control of ovo implantation. Vitams Horm. 31, 201.

Reik, L., Petzold, G. L., Higgins, J. A., Greengard, P. \& Barrnett, R. J. (1970) Hormone-sensitive adenyl cyclase: cytochemical localization in rat liver. Science, N.Y. 168, 382.

Robinson, G. A., Butcher, R. W. \& Suthert.And, E. W. (1971) Cyclic AMP and hormone action. In Cyclic AMP, pp. 17-47. Academic Press, New York and London.

Rosenfeld, M. G. \& O'MAlley, B. W. (1970) Steroid hormones: effects on adenyl cyclase activity and adenosine $3^{\prime}, 5^{\prime}$-monophosphate in target tissues. Science, N.Y. 168, 253.

Szego, C. M. \& Davis, J. S. (1967) Adenosine $3^{\prime}, 5^{\prime}$-monophosphate in rat uterus: acute elevation by estrogen. Proc. natn. Acad. Sci. U.S.A. 58, 1711.

TACHI, G., TACHI, S. \& LindNER, H. R. (1972) Modification by progesterone of oestradiol-induced cell proliferation, RNA synthesis and oestradiol distribution in the rat uterus. J. Reprod. Fert. 31, 59.

\section{EXPLANATION OF PLATE 2}

Fig. 4. Uterine epithelium of an ovariectomized rat treated with a single dose of progesterone $(5 \mathrm{mg})$. The apical plasma membranes are absolutely free of reaction product as in the case of the controls (Fig. 3). $\times 40,000$.

Fig. 5. Uterine epithelium of an ovariectomized rat which received three sequential injections of progesterone ( $5 \mathrm{mg} /$ day). Low levels of adenyl cyclase activity are found at discontinuous sites on the apical epithelial surfaces. $\times 40,000$.

FIG. 6. Uterine epithelium of an ovariectomized rat showing that the intensity of the enzyme activity shown in Fig. 5 was enhanced when the progesterone sequence was followed by a single dose of oestradiol $30 \mathrm{~min}$ before autopsy. The reaction product is preferentially confined to the microvilli of each epithelial cell. $\times 40,000$. 